\title{
The Unprivileged Socio-Political Classes \& Castes in India: A Study of the Naxalite Movement (1967-2008)
}

\author{
Muhammad Qasim Sodhar $^{1} *$ and Tugrul Keskin ${ }^{2}$
}

\begin{abstract}
The Naxalite movement is a famous movement going on in many districts of the different states of India. This movement is considered to be one of the biggest challenges to the Indian state. This study aims to look at the matter through historiography, investigating when this movement began and the root causes behind the movement. By consulting other studies already completed about this movement, it has been analyzed that the major cause behind the movement was the suppression of peasantry at the hands of the landlord, bourgeois, and capitalist classes, and as a result, the peasantry stood up against the cruelty of landlordism and killed one of the landlords in a remote village, Naxalbari, West Bengal. But later on, this movement turned against the mega-development projects set by multinational companies in collaboration with the government. Hence, this research is an attempt to present the historical events, causes, and motivations behind the launching and continuity of the movement. The study is based on secondary data by taking the relevant literature to learn the perspectives of both sides, i.e., Naxal leadership and also government authorities. In this regard, few reports set by different committees and commissions can be more helpful in understanding and analyzing matters.
\end{abstract}

Keywords: Naxalite; Naxalbari; Maoist; Neo-liberalism; India, Tribal Communities.

\section{Introduction}

The Naxalite movement began in 1967, in the village of Naxalbari situated in West Bengal - India. This movement was the beginning of a struggle by the peasant class against the cruelty of landlords of that area. Although initially this movement was not well organized due to negligence by the state in order to not listening to peasants' concerns, but this movement later took shape as an organized movement when the leaders of the Naxalite movement founded two political parties in 1969, namely the Communist Party of India (MarxistLeninist), and the Maoist Communist Centre (MCC). After the foundation of these parties, the Indian state shifted its negligence into coercive measures against the Naxalites. This was a major cause that led the movement to expand in many other parts of India. Instead of listening to the concerns of the

1 National Institute of Pakistan Studies (NIPS), Quaid-i-Azam University Islamabad, Pakistan.

2 Shanghai University, 99 Shangda Road, Baoshan Shanghai, 200444 China.

*)Corresponding Author.

Email: qasim_shu2016@yahoo.com 
people, the state labelled these Naxalites as "terrorists" and "anti-state elements."

The Naxalite movement got popularity in many other districts and states of India, especially in West Bengal, Uttar Pradesh, Jharkhand, and Chattisgarh. This movement is still stronger in areas where Adivasis (tribal population) is living. These tribal people are living worse lives than Dalits (lower-caste people). Dalits, also known as 'untouchables', constitutes onesixth of the Indian population (Jaoul, 2017). However, after reviewing the literature available on this topic, it seems that the Naxalite movement is not merely a movement to gain economic benefits, but also a movement for gaining self-esteem and recognition for Adivasis as equal citizens of the Indian state.

In order to look at the matter and the causes behind the emergence and expansion of this movement, the Indian government has appointed various committees and commissions to prepare reports on the matter to learn about the causes and solutions of the issue. In this regard, such a report was set up by the Planning Commission in 2006. This Planning Commission comprised of ex-bureaucrats, retired police officers, and well-known activists and academics - gave its report in March 2008, as entitled "Development Challenges in Extremist Affected Areas." While positioning out major causes behind the emergence of the Naxalite movement, the report identified a "directional shift in governmental policies towards modernization and mechanization, export orientation, diversification to produce for the market, withdrawal of various subsidy regimes and exposure to global trade" as "an important factor in hurting the poor in several ways" (Banerjee, 2008).

The aforementioned paragraph stated in the report of the Planning Commission indicated a "neo-liberal" development paradigm as a major root cause behind the resentment of tribal people (Naxalites). Thus, this study aims to look the matter within a paradigm of neo-liberalism, exploring whether development projects were harmful to people and concerned areas or whether it was something else, like mere politics of specific Naxalite leaders to get their interests. This movement began in 1967, but is still going on with the different factions of Naxalite political parties including the Communist Party of India (Marxist-Leninist), Maoist Communist Centre (MCC); Communist Party of India (Marxist-Leninist) Liberation; and Communist Party of India (Maoist).

Although the movement is still going on in the different parts of India, the period on which this study focuses is from 1967 to 2008, since the movement started. The purpose of selecting this period for this research study simply is that most of the literature consulted in this study revolves around that particular period.

To understand the matter theoretically, and also what has been going particularly in India in terms of the Naxal movement, this study looks at defining neo-liberalism. Apart from understanding neo-liberalism, this study looks at the matter of development, specifically the definition and concept of 
development, and looks at the scenario prevailing in areas of India where the Naxalite movement was going on during the selected period of the study.

After discussing neo-liberalism and development concepts, this study further discusses the Naxalite movement and analyzes its effects on Indian politics and internal conflicts which led to a division in the movement. To understand the motivation and causes behind the movement, it is necessary to understand the concept of neo-liberalism and also the development paradigm under neo-liberal ideology, because since few decades till today the neoliberal development, like mega development projects in tribal areas, has remained a major bone of contention between Naxalites and the state and government authorities. Therefore, before discussing the movement in its historical perspective, understanding what neo-liberalism is and what development mean is important.

\section{Neo-Liberalism as an Ideology and Concept of Development}

Neo-liberalism is connected with the capitalist ideology that advocates freedom for the individual, specifically free market. In David Harvey's words:

"Neoliberalism is in the first instance a theory of political economic practices that proposes that human well-being can best be advanced by liberating individual entrepreneurial freedoms and private property rights, free markets, and free trade. The state has to guarantee, for example, the quality and integrity of money. It must also set up those military, defence, police, and legal structures and functions required to secure private property rights and to guarantee, by force if need be, the proper functioning of markets" (2005).

Neo-liberalism, as defined by Harvey (2005), mainly advocates individual rights of free markets and if there is a need of force to maintain that right, it is no issue at all to use force. In this regard, the concerns of the tribal population of those areas where the Naxalite movement is going on are directly related to the neo-liberal development in the shape of mega projects. According to concerned companies and the government of India, these development projects were set for the welfare of the local population, but the Naxalites had been resisting that kind of development. Now the question arises: Why was the development denied by the leaders of the Naxal movement and, more importantly, what did the development mean specifically in concerned areas?

Development is not merely meant as just an increase in per capita income, but development is also the name of solving problems of poverty, unemployment, and inequality.

According to the World Bank statement issued in the 1991, World Development Report:

"The challenge of development is to improve the quality of life. Especially, in the world's poor countries, a better quality of life generally calls for higher incomes-but it involves much more. It 
encompasses as ends in themselves a better education, higher standards of health and nutrition, less poverty, a cleaner environment, more quality of opportunity, greater individual freedom, and a richer cultural life (as cited in Siddiqui et al., 2002)".

It is made quite a clear by the aforementioned World Bank statement that development should be linked to the better living standard of the people. In this respect, a mere increase in per capita or just focusing on infrastructure is not sufficient unless people are also provided with a quality of life which is the prime objective of development as defined by the various world-acclaimed organizations, including the World Bank. But a question arises here: Where does the problem lie that still so many countries, especially Third World countries, are deprived of satisfactory economic development? Is that condition prevailing because of the inefficiency of the governments of concerned countries? Is there any involvement from the outside, or is it an ideological failure of neo-liberal development? These possibilities behind the underdevelopment of Third World countries, specifically India, are discussed in this paper.

Neo-liberalism had emerged fully after the debacle of the Soviet Union when the Communist bloc collapsed and now only one ideological camp, the Capitalist one, remained and controlled the world economic and political order. This was after the emergence of neoliberalism that the NonGovernmental Organizations (NGOs) came on the surface. The NGOization, also known as 'civil society', was projected as the alternative to communism and socialism. Although after the debacle of the Soviet Union, the left had already faced many challenges, right after this NGOization process, now the political trends had been changed slightly. Therefore, like the rest of the world, the politics of India, including the politics of marginalized and subaltern communities, including tribal people and Dalits, could not remain unaffected. Ultimately, the de-politicization in the name of liberalism and development started throughout India including areas where the movement for the rights of marginalized communities was going on.

In India, Dalit movement has a long history as launched by an Indian jurist, Bhimrao Ramji Ambedkar, who challenged the caste system, and also launched struggle through demanding equal rights for all Dalit communities in India because of caste system prevailing in Hinduism, the Dalits or people of the lower caste, were treated as untouchables who could not enter in temples , and could not drink water from the same pond from which other people, especially the Brahman (higher caste people) used to drink. Hence, after the British left India, and despite the death of Ambedkar happened in 1956, this movement continues till today. There are different factions within the Dalit movement as well. As Nicolas Jaoul (2017), describes:

"The anti-caste ideology of what I will refer to as the 'traditional' (i.e. the existing, non-NGOized) Ambedkarite movement combines a strong sense of Dalit communitarian identity and autonomy with 
ideological references to political modernity. Politically it can be summarized by its historical leader Ambedkar (1891-1956), whose influences combined liberal thought with Buddhism as well as a critical engagement with Marxism (p. 3)".

Apart from this Ambedkarite movement, another faction of movement, which believes in parliamentary politics, is called Bahujan Samaj Party (BSP) in the Uttar Pradesh state of India. However, this group also believes in a political solution, but as the neo-liberal thought is concerned, the other school of thought among Dalits is also related to the NGOization of the movement. This trend started when in the 1980s the Dalit activists and Diaspora (mainly based in the UK) initiated contacts to the United Nations Human Rights Council. And this was initiated formerly when the National Campaign for Dalit Human Rights (NCDHR) was founded by a former Marxist-Leninist namely Paul Diwakar (Jaoul 2017).

Apart from the NGOization of the Dalit movement, the same had happened with the Naxalite movement through this neo-liberalization and NGOization. In this regard, later on, another NGO, the Dynamic Action Group (DAG), was founded by another former leader of the Naxalite Movement, namely Ram Kumar, in 1998.

The head and founder of this network -Ram Kumar is a Dalit from U.P. and a former member of the CPI-ML (Communist Party of IndiaMarxist-Leninist) or Naxalite Party, which was clandestine and engaged in armed struggle at the time when he was part of it. He left party in the mid1980s because he felt that it did not attach enough importance to the question of caste and because of the various forms of caste domination and exploitation of Dalits inside the organization, which was controlled by the upper-caste intellectuals...the DAG's blog presents its main objectives as being 'to reinforce the concept and philosophy of Dalit emancipation' and 'to produce training and education in order to create a new leadership' (Jaoul, 2017).

The NGOization of the political movements has also remained a big issue. In this pattern, Lamia Karim (2016) mentions an interview with a former Communist Party member who narrates:

"We would go to villages, and find that the NGO workers had urged villagers not to come to our meetings. They would tell villagers, 'Why go to them? What can they give you?' Hence instead of fighting the military, we fought NGO that we saw as depoliticizing our work. After the 1990s, the communist parties have realized that we do not live in a bipolar world (p. 6)".

From an aforementioned interview of a former member of the Communist Party, one can analyze that how this project of NGOization or neo-liberalism, has been trying depoliticizing people.

However, in order to understand the matter, it is necessary to first go through the history of the movement. 


\section{Causes of the Movement}

In India, the different kinds of problems have been prevailing, such as class, caste, gender, and religious conflicts. During the British period, there was a huge gap between the living standards of indigenous Indians and the British authorities in India. But at the same time, there was a clear difference within India's communities as well. Thus, on the one hand, because of religious differences, which were used by the British to follow their "divide and rule" policy, clashes between Hindus and Muslims and between Sikhs and Muslims were providing grounds for the British to exploit this phenomenon more. However, apart from religious conflicts, there was the problem of caste-ism with the Hindu religion as well.

In the Hindu religion, castes related to the "Brahman" had entertained major power and positions. On the other side, there are "Dalits," lower-caste people who were not allowed to sit and eat with Brahmans, because Dalits were declared as untouchables who were born just for serving Brahmans, cleaning their houses, streets, and roads. They were not even allowed to drink and eat in the same pots which Brahmans used to drink and eat. By looking at this critical condition of Dalits, and also experiencing such injustices with that particular community, B. R. Ambedkar was the person from this same Dalit community who stood against such discrimination and launched a movement against the supremacy of Brahmans. As a result of struggles under his leadership, he succeeded by at least gaining some benefits and recognition for Dalit communities that had not been thought of by anyone of that community before.

On the other hand, there were other marginalized communities in India who were called tribal people. They had been living in tribal areas in forests, and these areas had been disconnected from major areas of the country. A year before the British left, the All India Congress leader -Jawaharlal Nehru, moved the Objective Resolution in Constituent Assembly on December 13, 1946. In this resolution, people from all walks of life were guaranteed to be safeguarded and given equal rights once the British who were supposed to leave the country. According to the resolution, once India got freedom, "its Constitution would guarantee citizens justice, social, economic and political; equality of status; of opportunity, and before the law; freedom of thought, expression, belief, faith, worship, vocation, association and action, subject to law and public morality" (Guha, 2007). About the rights of backward communities, the resolution specifically states that "adequate safeguards shall be provided for minorities, backward and tribal areas, and depressed and other backward classes" (Guha, 2007).

In response to that Objective Resolution, Jaipal Singh, an assembly member from one of the tribal areas, said,

"I am not expected to understand the legal intricacies of the

Resolution. But my common sense tells me that every one of us should march in that road to freedom and fight together. Sir, if 
there is any group of Indian people that has been shabbily treated it is my people. They have been disgracefully treated, neglected for the 6,000 years. The history of the Indus civilization, a child of which I am, shows quite clearly that it is the newcomers-most of you here are intruders as far as I am concerned-it is the newcomers who have driven away my people from the Indus Valley to the jungle fastness. . . . The whole history of my people is one of continuous exploitation and dispossession by the nonaboriginals of India punctuated by rebellions and disorder, and yet I take Pandit Jawaharlal Nehru at his word. I take you all at your word that now we are going to start a new chapter, a new chapter of independent India where there is equality of opportunity, where no one would be neglected. (Guha, 2007)".

Among other causes of the movement, the development process before the movement started was also responsible for the movement beginning in tribal areas.

According to the different studies in terms of development, Adivasis (tribals) had lost more than they got. According to the estimation of sociologist Walter Fernandes, who was quoted by Ramchandra Guha (2007):

"About 40 per cent of all those displaced by government projects are of tribal origin. Since adivasis constitute roughly 8 percent of India's population, this means that a tribal is five times as likely as a non-tribal to be forced to sacrifice his home and hearth by the claims and demands of development and/or conservation ( $p$. 3306)".

The Home Ministry of India constituted a committee headed by anthropologist Verrier Elwin, a decade after India got freedom. The purpose of constituting this committee was to know about the schemes being run by the government in these tribal areas. This committee studied 20 blocs across the country and, based on that study, the committee concluded that much of the poverty and other related problems in concerned areas were:

"The fault of us, the "civilised" people. We have driven [the tribals] into the hills because we wanted their land and now we blame them for cultivating it in the only way we left to them. We have robbed them of their arts by sending them the cheap and tawdry products of a commercial economy. We have even taken away their food by stopping their hunting or by introducing new taboos which deprive them of the valuable protein elements in meat and fish. We sell them spirits which are far more injurious than the home-made beers and wines which are nourishing and familiar to them; and use the proceeds to uplift them with ideals. We look down on them and rob them of their self-confidence, and 
take away their freedom by laws which they do not understand (Guha, 2007)".

After some time, another high-powered committee, chaired by senior congressman U. N. Dhebar was constituted. This committee consisted of six members of Parliament, including Jaipal Singh, who had already raised a voice for tribals in response to the Objective Resolution moved by Jawaharlal Nehru. The report was published by the Government Press in 1961. The report stated:

"There is constant propaganda that the tribal people are destroying the forest. We put this complaint to some unsophisticated tribals. They countered the complaint by asking how they could destroy the forest. They owned no trucks; they hardly had even a bullock cart. The utmost that they could carry away was some wood to keep them warm in the winter months, to reconstruct or repair their huts and carry on their little cottage industries. Their fuel needs for cooking, they said, were not much, because they had not much to cook. Having explained their own position, they invariably turned to the amount of destruction that was taking place all around them. They reiterated how the ex-zamindars, in violation of their agreements, and the forest rules and laws, devastated vast areas of forest land right in front of officials. They also related how the contractors stray outside the contracted coupes, carry loads in excess of their authorised capacity and otherwise exploit both the forests and the tribals (Guha, 2007)".

Despite all of these reports of the different committees on the status of tribal areas and the people, unfortunately in spite of promises by Jawaharlal Nehru and other leaders of the Indian National Congress, the problems of the deprivation of tribal people did not resolve, and ultimately these problems led to the movement against state apparatus.

\section{The Movement Begins}

It is an interesting to note that the Naxal movement began from a remote and small village, Naxalbari, and not from an urban city. At the same time, it was also interesting that the movement was started and led not by the middle or bourgeois class, but by peasants of the area, and ultimately the movement expanded to other areas of India. How the Naxal movement began and can be understood by looking at the analysis by Rajat Kujur (2008), who wrote that:

"In a remote village called Naxalbari in West Bengal, a tribal youth named Bimal Kissan, having obtained a judicial order, went to plough his land on 2 March 1967. The local landlords attacked him with the help of their goons. Tribal people of the area retaliated and started forcefully recapturing their lands. What 
followed, and was a rebellion, which left one police sub inspector and nine tribals dead (p. 2)"'.

There are the different points of view about the Naxal movement. The Naxalites claim that the movement was a reaction to injustices that had been happening with tribal people done by state and government authorities. But on the other hand, government officials reject these claims of Naxalite leaders, and government authorities label Naxalite leaders as anti-state and agents of foreign forces. The Communist Party of India (Marxist), an important and major left-wing group that has been leading a section of the movement, claims that "behind the peasant unrest in Naxalbari lies a deep social maladymalafide transfers, evictions and other anti-people actions of tea gardeners and jotedars" (Dixit, 2010). It is to be noted here that the movement started and got momentum in those areas where people had been facing severe poverty (Dixit, 2010). At the initial stage when this movement was started in 1967, the government officials, specifically the then-Home Minister Y. B. Chawan declared the movement as just "lawlessness" (Dixit, 2010). But within a twoyear time period, the movement expanded to other areas, especially tribaldominated areas of Andhra Pradesh. Then the high authorities of the thengovernment had asked Chawan to prepare a report about the causes of the movement. The then-Home Minister Chawan prepared a report entitled "The Causes and Nature of Current Agrarian Tensions," prepared by the research and publicity division of Chawan's Home Ministry. The report stated:

"The basic cause of unrest, namely, the defective implementation of laws enacted to protect the interests of the tribals, remains; unless this is attended to, it would not be possible to win the confidence of the tribals whose leadership has been taken over by the extremists (Banerjee, 2002)."

It was a clear example of negligence by the State authorities and claiming that the Naxal movement was mere lawlessness; the movement expanded in many other areas of India.

\section{Effects of the Movement and the Indian State's Response}

Because of the deprivation of different classes, castes, and religious elements, this movement did not remain a phenomenon only of the village Naxalbari, but expanded into other parts of India. There were immediate effects of the Naxalbari incident within a short period of only two months, the movement got support from the communist revolutionaries, specifically the state units of CPI (M-L) (Marxist-Leninist), West Bengal, Tamil Nadu, Uttar Pradesh, Kerala, Jammu and Kashmir, Orissa, and Bihar (Kujur, 2008). "State response to the Maoist insurgency has evolved over the years, and influenced by both the intensity of threat as well as the nature of political dispensation at the Centre and the affected states" (Sahoo, 2019). Because of the popularity of the movement, the government of West Bengal took severe measures against the 
movement. In order to face state repression, the communist revolutionaries, who extended their support to the cause of the peasants of the village Naxalbari, held a meeting in November 1967. As a result of this meeting, in May 1968, the All India Coordination Committee of Communist Revolutionaries (AICCCR) was formed (Kujur, 2008).

Initially, two objectives of AICCCR were decided which were to support the armed struggle and not to participate in elections. But within a short span of time, the differences over the issue of armed struggle took place that led to a division within the movement through the formation of two factions. One faction, who was functional in Andhra Pradesh, and led by T. Nagi Reddy, and the other faction, as led by Kanhai Chatterjee, represented communist revolutionaries of West Bengal (Kujur, 2008). Initially, the movement was not well- organized, but in 1969, the Communist Party of India (Marxist-Leninist) led by Kanhai Chatterjee, and founded that gave strength to the cause of tribal people.

The CPI (M-L) held its first convention in 1970, in which Charu Mazumdar was elected as the general secretary, declaring the decade of the 1970 s as the "decade of liberation" from the semi-feudal and semi-colonial rule in India. In retaliation, the Indian state declared the 1970s as the "decade of repression" (Banerjee, 2002). The communiqué of CPI (M-L) highlighted the formation of the party in these words:

"The All India Co-Ordination Committee of Communist Revolutionaries, which met in a plenary session from 19th to 22nd April 1969, announces the formation of the revolutionary party, Communist Party of India (Marxist-Leninist) based on the thought of Mao Tse-tung on 22nd April 1969, the one-hundredth birthday of Great Lenin - a task it set itself eighteen months ago, in November 1967-and also announces its own dissolution after setting up a Central Organising Committee to hold Congress at an appropriate time (Mohan, 1970)".

Charu Mazmudar became a Naxalite guru all over India wherever the Maoist movement was going on. He was backed by the Chinese Communist Party ;andevident from Peking Radio transmissions and also Chinese Communist papers in which Charu's articles were being frequently referenced (Mohan, 1970). CPI (M-L) that was a major party leading the Naxalite movement. It stated during the very initial days of the party that "India is a semiComprador-bureaucrat capitalist, and . . . its Government is lackey of US imperialism and Soviet social-imperialism" (Mohan, 1970).

Although the struggle led by CPI (M-L) expanded through other parts of India, it was short lived. Rajat Kujur (2008) wrote that "as hundreds of CPI (ML) cadres lost their lives, and thousands were put behind bars, the movement witnessed confusion, splits and disintegration" (p. 3). After the death of Charu Mazmudar in 1972, the CPI (M-L) leadership collapsed (Kujur, 2008). 


\section{Internal Conflicts and Splits within the Movement}

Before the division occurred in CPI (M-L), this was not the only party that was representing the Naxalite movement; in the same year when CPI (M-L) formed, another party, the Maoist Communist Centre (MCC), was also formed on October 20, 1969. The MCC was inspired by the teachings of Mao Zedong and the Chinese revolution, as seen in its party program, which stated:

"This armed revolutionary war is the war of the armed people themselves; it is "Protracted People's War" as shown by Mao Tse Tung. The concrete economic and political condition of India leads to the very conclusion that the path shown by the great leader and teacher, Mao Tse Tung, the path of the Chinese revolution, that is, and to establish a powerful people's army and people's militia and to establish dependable, strong and self-sufficient base areas in the countryside, to constantly consolidate and expand the people's army and the base areas, gradually to encircle the urban areas from the countryside by liberating the countryside, finally to capture the cities and to establish the state system and political authority of the people themselves by decisively destroying the state power of the reactionaries - this very path of the protracted People's War is the only path of liberation of the people of India, the path of victory of the new democratic revolution (Kujur, 2008)".

The MCC had been working independently without being a faction of the CPI (M-L), and in 2004 it merged with CPI (Maoist). But in the meantime, divisions within CPI (M-L) were taking place. Charu Mazmudar was recognized as the Naxalite guru (leader of all Naxalites), so there was no such conflict arisen during his life that could lead to any division in the movement. But, after his death in 1972, the movement faced a series of divisions and the formation of new factions. The first organized faction after CPI (M-L) formed was the Communist Party of India (Marxist-Leninist) Liberation, in 1974 (Kujur, 2008).

The Communist Party of India (Marxist-Leninist) Liberation rejected Charu Mazmudar's strategy of guerrilla war and this new faction focused instead on mass mobilization. Also, CPI (M-L) Liberation decided to contest elections to be a part of electoral and parliamentary politics. In this way, they expanded their struggle in many other parts of the country by founding the different pockets of struggle. In this respect, Manoranjan Mohanty (2006), wrote about the struggles and formation of sister organizations of CPI (M-L) Liberation:

"Their mass organizations have an All-India character, and have pockets of influence in different parts of the country: the trade unions, in the All India Agriculture Labour Association (AIALA), the All India Students Association (which has a strong base in JNU) as well as the All India Progressive Women's Association 
(AIPWA). They have won seats in the Bihar legislative assembly and have played an important role in Bihar politics as well. They have occasionally had a member elected to Parliament as well (p. 3165)".

This kind of division within the movement continued. In April 1980, CPI (ML) Liberation further divided when a new faction named the Communist Party of India (Marxist-Leninist) People's War Group was formed in Andhra Pradesh. The faction, later known as CPI (Maoist), followed Charu Mazmudar's line by rejecting the idea of CPI (M-L) Liberation of participating in electoral politics, and later on, this faction became a very powerful group of the Naxalite movement (Mohanty, 2006). The CPI (Maoist) faction started its struggle from Telangana and expanded its functioning in Bihar when, in 1996, the Party Unity group was merged with it. This group gained much popularity and became most powerful when the Maoist Communist Centre (MCC) also merged with it in 2004 (Mohanty, 2006). But before the merger with the MCC, the People's War Group (PWG), which was renamed later as CPI (Maoist), was also powerful in different parts of the country. Also, this Maoist group "is a member of the Coordination Committee of Maoist Parties and Organisations of South Asia (CCOMPOSA), an umbrella organisation that serves as a discussion platform for Maoist parties in the subcontinent, and it is believed to have mainly provided moral support in the past" (A historical introduction to Naxalism in India, 2019).

The movement is yet going on and expanding to different areas of the country, and it is also surprising that despite divisions within the movement, the strength and number of guerilla fighters have been exceeding. According to estimates:

"There are perhaps between 10,000 and 20,000 full time guerrillas, many of them armed with an AK-47. These revolutionaries are also conversant with the use of grenades, landmines, and rocketlaunchers. They maintain links with guerilla movements in other parts of South Asia, exchanging information and technology with the Liberation Tigers of Tamil Eelam and, at least before their recent conversion to multiparty democracy, with the Nepali Maoists (Guha, 2007)".

Likewise, in 2006, when the movement spread over 165 districts in 13 states of India, the then-Prime Minister of India, Manmohan Singh, declared the Naxal movement as the "single biggest internal security challenge" to India (Mohanty, 2006).

\section{Conclusion}

Answering the question, i.e., whether development projects were really harmful to the people and concerned areas, or whether it was something else like mere politics of Naxalite leaders to get their personal interests, this study 
concluded that the root causes behind the emergence of the movement can be traced from severe poverty prevailing in concerned areas. Also, before the emergence of the Naxal movement, the development process adopted by the then-government was also considered as anti-tribal people. At the same time, the cruelty of landlords against the peasantry class was a major phenomenon that fueled the anger of people of the village of Naxalbari. As far as exploiting local population for personal interests by the Naxalite leaders is concerned, it could be possible, but because problems had prevailed there, and the government authorities failed to resolve these problems, ultimately peasants stood against the cruelty of landlordism, and the Naxal movement started. However, it can be concluded that, on the one hand, the leaders of the Naxalite movement have been trying to change the system through bring the peasantry and other marginalized classes on the forefront, on the other hand, the Indian government has also been trying to divert the people's attention from this movement through propagating the narrative of development. In this way, development paradigm and the NGOization of the movement have tried its best to de-politicize movement. But, still, the Naxalite threat to Indian government is there.

\section{References}

A historical introduction to Naxalism in India. (2019). Retrieved from European Foundation for South Asian Studies (EFSAS), Amsterdam website: https://www.efsas.org/publications/study-papers/an-introductionto-naxalism-in-india/

Banerjee, S. (2008). On the Naxalite movement: A report with a difference. Economic and Political Weekly, 43(21), 10-12.

Banerjee, S. (2002). Naxalbari: Between past and future. Economic and Political Weekly, 37(22), 2115-2116.

Dixit, R. (2010). "Naxalite movement in India: The State's response". Journal of Defence Studies, 4(2), 21-35.

Guha, R. (2007). Adivasis, Naxalites and Indian democracy. Economic and Political Weekly, 42(32), 3305-3312.

Harvey, D. (2005). A brief history of neoliberalism. New York, NY: Oxford University Press.

Jaoul, N. (2017). Politics Against the Grain: The Dalit Movement of Uttar Pradesh in the Throes of NGOization. Critical Sociology, 1-17.

Karim, L. (2016). Reversal of Fortunes: Transformations in State-NGO Relations in Bangladesh. Critical Sociology, 1-16.

Kujur, R. (2008). Naxal movement in India: A profile. New Delhi, India: Institute of Peace and Conflict Studies (IPCS).

Mohan, J. (1970). Naxalites, the new left. Economic and Political Weekly, $5(29 / 31), 1119,1121-1122$.

Mohanty, M. (2006). Challenges of revolutionary violence: The Naxalite movement in perspective. Economic and Political Weekly, 41(29), 31633168 . 
Sahoo, N. (2019). Half a Century of India's Maoist Insurgency: An Appraisal of State Response. Observer Research Foundation (198). Retrieved from https://www.orfonline.org/research/half-a-century-of-indias-maoistinsurgency-an-appraisal-of-state-response-51933/

Siddiqui, F. A., Jabeen, B. S., \& Mahmood, N. (2001). Importance of a population policy in Pakistan [with comments]. The Pakistan Development Review, 40(4), Papers and Proceedings PART I Seventeenth Annual General Meeting and Conference of the Pakistan Society of Development Economists, Islamabad, January 14-16, 2002 (Winter 2001), 345-369. 